\title{
THE VALIDITY OF THE BAPTISM OF HERETICS ACCORDING TO CYPRIAN OF CARTHAGE, POPE STEPHEN AND FIRMILIAN OF CAESAREA
}

Since the beginning of Christianity it has been obvious that baptism absolved sins. There were theologians who believed only in the validity of the baptism administrated in the Catholic Church, but not in heretical sects. They understood baptism as a sacrament that introduces people into the Church. Consequently, they were not able to accept the baptism of heretics. They asked: How can someone who is outside the Church introduce others into the Church? Other theologians put the accent on the efficacy of the sacrament of baptism: the rite itself performed in the name of the Father and of the Son and of the Holy Spirit produces its effect in spite of the person who administrates it (ex opere operato). Consequently, they accepted the baptism received in sects. The conflict exploded in Africa. According to Saint Cyprian, the baptism of heretics had no validity. Pope Stephen accepted the validity of such a baptism. The difference of opinions launched a great debate among theologians and bishops.

There are many publications on this subject such as Georges Bareille ${ }^{1}$, Pierre Gaudette ${ }^{2}$, Maurice Bénevot ${ }^{3}$, Mireille Labrousse ${ }^{4}$, Jerzy Podolecki ${ }^{5}$. The article by Celestyn Napiórkowski shows that the validity of baptism is not only a historical question, but it is also a subject of discussion among Christian Churches and communities in our time ${ }^{6}$.

* Rev. Dr hab. Joseph Grzywaczewski, prof. UKSW - professor in patristic theology at University Stephan Cardinal Wyszynski in Warsaw (Faculty of Theology); e-mail: j.grivalles@ gmail.com.

${ }^{1} \mathrm{Cf}$. G. Bareille, Baptême des hérétiques, DThC II 219-233.

${ }^{2}$ Cf. P. Gaudette, Baptême et vie chrétienne chez Cyprien de Carthage, Québec 1971.

3 Cf. M. Benevot, Cyprian's platform in the rebaptism controversy, "Heythrop Journal" 19 (1978) 123-142.

${ }^{4}$ Cf. M. Labrousse, Le baptême des hérétiques d'après Cyprien, Optat et Augustin: influences et divergences, REAug 42 (1996) 223-242.

${ }^{5}$ Cf. J. Podolecki, Szafarz sakramentu w starożytności chrześcijańskiej, SW 4 (1968) 363-279.

6 Cf. C. Napiórkowski, O ważności chrztu $w$ niektórych Kościołach $i$ wspólnotach chrześcijańskich $w$ Polsce CT 41 (1971) fasc. 3, 41-59. See T. Maertens, Histoire et pastorale du rituel du catéchuménat et du baptême, Bruges 1962. 
The aim of this article is not to present the totality of this problem, but only to introduce the reader to the atmosphere of misunderstanding and debate among three theologians: Cyprian, Stephen, and Firmilian. Each of them believed that he was keeping the Apostolic teaching in this matter. In fact, they kept the same Christian faith, but they were following different traditions concerning baptism.

1. The position of Saint Cyprian. There were people in Africa in the time of Saint Cyprian who at first belonged to a sect and later wanted to join the Catholic Church. Cyprian was ready to accept them, but he did not hold their baptism as valid. He wrote about it in his letter to Jubaianus (Iubaianus):

"Can the power of baptism be greater or of more avail than confession, than suffering, when one confesses Christ before men and is baptized in his own blood? And yet even this baptism does not benefit a heretic, although he has confessed Christ, and been put to death outside the Church, unless the patrons and advocates of heretics declare that the heretics who are slain in a false confession of Christ are martyrs, and assign to them the glory and the crown of martyrdom contrary to the apostle, who says that it profit them nothing although they burnt and slain. But if not even the baptism of a public confession and blood can profit a heretic to salvation, because there is no salvation out of the Church (salus extra Ecclesia non est), how much less shall it be of advantage to him, if in a hiding-place and a cave of robbers, stained with the contagion of adulterous water, he has not only put off his old sin, but rather heaped up still newer and greater ones!"”

As we see, Cyprian did not accept the baptism of the heretics. He was severe, saying: Such a baptism does not benefit a heretic, although he has confessed Christ and been put to death. Those who die for Christ's sake as heretics, in fact die outside the Church; their sect can be compared to a cave of robbers. He also called them Antichrists ${ }^{8}$. If they live and die outside the Church, they have no communion with Christ. If they have no communion with Christ, they cannot be saved, even if they proclaim their faith with their lips. They should remain in the Church and proclaim Christ with their heart. Cyprian was very far away from the attitude nowadays called ecumenism. Indeed, there was no ecumenism in that time.

Jerzy Pałucki stresses that Cyprian's famous declaration from the same letter - salus extra Ecclesia non est - is not to be understood as a statement concerning the salvation of humanity; Cyprian did not want to say that all

${ }^{7}$ Cyprianus, Epistula 73, 21, ed. G. Hartel, CSEL 3/2, Vindobonae 1868, 795, transl. E. Wallis, ANF 5, Massachusetts 1999, 384 (Epistula LXXII 21). Cyprian's letters have not the same numbers in the edition by CSEL and by ANF.

${ }^{8}$ Cf. Labrousse, Le baptême des hérétiques d'après Cyprien, p. 227: "Pour Cyprien les schismatiques et les hérétiques sont les antéchrists dont parle Jean (1Jn 2:18)". 
people who did not belong to the Church would be condemned. He did not speak about general salvation. He expressed this opinion in the context of the disorder in the Church in Africa in that time ${ }^{9}$. His aim was to encourage people to keep the unity of the Church. He tried to show the superiority of the Church over sects. He referred to the Old Testament:

"God had no respect to Cain's offerings; for he could not have God at peace with him who through envious discord had not peace with his brother. What peace, then, to the enemies of the brethren promise themselves? What sacrifices do those who are rivals of the priests think that they celebrate? Do they deem that they have Christ with them when they are collected together, who are gathered together outside the Church of Christ? Even if such men were slain in confession of the Name, that stain is not even washed away by blood; the inexpiable and grave fault of discord is not even purged by suffering. He cannot be a martyr who is not in the Church; he cannot attain the Kingdom who forsakes that which shall reign there. Christ gave us peace. He bade us be in agreement, and of one mind. He charged the bonds of love and charity to be kept uncorrupted and inviolate. He cannot show himself a martyr who has not maintained brotherly love"10.

God did not accept Cain's offering because his way of living was wrong; he lived in discord with brother, he was jealous of him, he had no peace with him, and finally killed him. Heretics have not peace with other Christians, and they are not union with Christ. This unity, commanded by Christ, is so important that, even if someone dies for Christ's sake, yet remained out of the Church, he cannot be considered a martyr. The sins of such people cannot be washed by their suffering and death. If they want to experience God's mercy, they should come to the Catholic Church, and they should be baptized once again.

After having given such an important explanation, Cyprian continues his teaching on baptism:

"Wherefore baptism cannot be common to us and to heretics, to whom neither God the Father, nor Christ the Son, nor the Holy Spirit, nor the faith, nor the Church itself, is common. And therefore it behoves (concerns) those to be baptized who come from heresy to the Church, that so they who are prepared, in the lawful, and true, and only baptism in the holy Church, by divine regeneration, for the kingdom of God, may be born of both sacraments, because it

${ }^{9}$ Cf. J. Pałucki, Poza Kościołem nie ma zbawienia. Od Orygenesa i Cypriana do Fulgencjusza, in: Wczesne chrześcijaństwo a religie, ed. S. Ledwoń - M. Szram, Lublin 2012, 648: „Nic nie wskazuje na to, że Cyprian chciał tą formułą podkreślić, że ogromna liczba ludzi, nieznających Ewangelii i nieochrzczonych, będzie potępiona. Nie prowadził spekulacji na temat zbawienia ludzkości, a jedynie zabiegał o jedność Kościoła, który jako zjednoczony potrzebny jest wszystkim”.

${ }^{10}$ Cyprianus, De catholicae Ecclesiae unitate 13-14, ed. G. Hartel, CSEL 3/1, Vindobonae 1868, 221-222, transl. E. Wallis, ANF 5, 425-426. 
is written, «Except a man be born of water and of the Spirit, he cannot enter into the kingdom of God» (Jn 3:5)"'11.

According to Cyprian, the baptism administrated in the Church and the baptism administrated in sects must not be confused: they do not have the same validity. The baptism of the heretics does not produce any effect, it is just a rite $^{12}$. Only the baptism received in the Church introduces the faithful into the life of the Father and the Son and the Holy Spirit. Such a baptism produces the true regeneration. People are regenerated not by a gesture or a rite but by Christ himself. Cyprian's famous declaration was:

"As the birth of a Christian is in baptism, while the generation and sanctification of baptism are with the spouse of Christ alone. Who is able spiritually to conceive and to bear sons to God? Where and of whom and to whom is he born, who is not a son of the Church, so as that he should have God as his Father, before he has had the Church for his Mother (ut habere quis posit Deum patrem, habeat ante ecclesiam matrem)?"'13.

While speaking about God as Father, Cyprian was referring to the Bible. In Jeremiah's prophecy, the people of Israel say to God: "You are my Father, and you have loved me since I was a child" (Jer 3:4). God has accepted the fatherson relationship: "The Lord says: Israel, I wanted to accept you as my child and give you a delightful land, the most beautiful land in the world. I wanted you to call me Father, and never again turn away from me" (Jer 3:19). Jesus Christ spoke many times about God as his Father and Father of others. Christians should pray: "Our Father who art in heaven" (Mt 6:9). After his resurrection Jesus said: "I am going to my Father and your Father, to my God and your God" (Jn 20:17). The comparison of the Church to mother is also based on the Bible. Neither in the Old Testament nor in the New Testament was the Church called mother, but there are passages where the relationship between God and his people is presented as the relationship between husband and wife. Prophet Isaiah wrote about Jerusalem: "Because the Lord is pleased with you, he will be a husband to your land. Like a young man taking a virgin as his bride, he who formed you will marry you. As a groom is delighted with his bride, so your God will delight in you" (Is 62:5). Saint Paul was following this comparison while speaking about the relationship between Christ and Church: "The husband is head of his wife just as Christ is head of the Church [...]. Husbands, love your wives as Christ loved the Church and handed himself for her" (Eph 5:24-25).

${ }^{11}$ Idem, Epistula 73, 21, CSEL 3/2, 795, ANF 5, 385 (Epistula LXXII 21).

${ }^{12}$ Cf. Labrousse, Le baptême des hérétiques d'après Cyprien, p. 229: "Pour Cyprian, en dehors de la vraie foi (dans l'hérésie), en dehors de la vraie Église (dans le schisme), le baptême ne peut pas exister".

${ }^{13}$ Cyprianus, Epistula 74, 7, CSEL 3/2, 804, ANF 5, 388 (Epistula LXXIII 7). 
Generally, theologians accept that "it is most significant that Ephesians compares the relationship between wife and husband directly to that between Christ and Church [...]. A wife's subordination to her husband is to correspond, first, to her own subordination to Christ, and second, to the Church's subordination to Christ" 14 . If the Church is presented as Christ's wife, it is normal that Christians as God's children in Christ (filii in Filio) can be considered as the Church's children as well. In this sense, the Church is our Mother. In Latin and Greek the word Church (ecclesia, $\dot{\varepsilon} \kappa \kappa \lambda \varepsilon \sigma^{\prime} \alpha$ ) is female. In English, it is accepted, while speaking about the Church, to use the pronouns she and her.

It was clear for Cyprian that only those who have God as Father can have the Church as Mother. God does not cooperate with sects, but only with his Church. In Cyprian's concept there was no place for heresy. He desired to show the difference between the Catholic Church and heretic groups.

The synods of Carthage in 255 confirmed such a position. We know the decision of this synod from Letter 70 of Cyprian. The bishops declared:

"No one can be baptized outside of the Church, since there is one baptism appointed in the holy Church (neminem foris baptizari extra Ecclesiam posse, cum sit baptisma unum in Ecclesia constitutum)" ${ }^{15}$.

They explained:

"If one could baptize, he could also give the Holy Spirit. But, if he cannot give the Holy Spirit [...], he cannot baptize those who come; since both baptism is one and one is the Holy Spirit" ${ }^{\prime \prime}$.

It was obvious for Cyprian that the Holy Spirit (who is one) was acting (is acting) only in one Catholic and Apostolic Church, but not in Christian groups separated from the Church.

Two others synods in Carthage, both in 256, confirmed the African practice of baptizing the heretics coming to the Church from sects. A total of 71 bishops participated in the first synod; in the second, 85 bishops. All of them were unanimous in stating that heretics, if they come to the Church, should be baptized once again ${ }^{17}$. The bishops agreed with Saint Cyprian. It is interesting to notice that African bishops, who had not agreed with the Pope, did not condemn directly the Roman (Italian) practice of holding the baptism of heretics as valid ${ }^{18}$. Divergence in this matter did not produce schism.

${ }^{14}$ Th.R. Yoder Neufand, The Commentary to the Letter to Ephesians, in: Believers Church Bible Commentary, ed. E.A. Martens - W.M. Swartley, Waterloo - Ontario 2002, 255-256.

${ }^{15}$ Cyprianus, Epistula 70, 1, CSEL 3/2, 767, ANF 5, 375 (Epistula LXIX 1).

${ }^{16}$ Ibidem 70, 3, CSEL 3/2, 769: "Si autem Spiritum Sactum dare non potest, quia foris constitus cum Sancto Spiritu non est, nec baptizare potest, quando et baptisma unum sit", ANF 5, 376 (Epistula LXIX 3).

${ }^{17}$ Cf. Mansi I 951-992.

${ }^{18}$ Cf. L. Pietri, Les résistances: de la polémique païenne à la persécution de Dioclétien, in: 
2. The position of Pope Stephen and of the Church of Rome. The Roman Church rejected the opinion of Cyprian and African bishops at the synod of Rome in 255/256. According to Eusebius, the bishops participating in this synod made the following decision:

"Lucius died in less than eight months, and transmitted his office to Stephen. Dionysus (bishop of Alexandria) wrote to him the first of his letters on baptism, as no small controversy had arisen as to whether those who had turned from any heresy should be purified by baptism. For the ancient custom prevailed in regarding to such, that they should receive only the laying on of hands with prayers. First of all, Cyprian, pastor ( $\pi \rho \hat{\omega} \tau 0 \varsigma)$ of the parish of Carthage, maintained that they should not be received except they had been purified from their error by baptism. But Stephen, considering it unnecessary to add any innovation contrary to the tradition which had been held from the beginning, was very indignant at this" ${ }^{\prime 19}$.

The term "parish" ( $\left.\pi \alpha \rho \circ \kappa_{i} \alpha\right)$ is implied to a local Christian community ${ }^{20}$. Nowadays, we say: diocese. There was a misunderstanding: Cyprian believed that he was following the oldest Christian tradition; Stephen underlined that his point of view was conforming to the oldest tradition in Christianity. Both solutions were applied in Churches. Eusebius was probably not sure which way was better; he wrote about Cyprian and Stephen without expressing his own opinion on this question.

Pope Stephen wrote to Cyprian:

"If any one, therefore, come to you from any heresy whatever, let nothing be innovated which has not been handed down, to wit, that hands be imposed on him for repentance; since the heretics themselves, in their own proper character, do not baptize such as come to them from one another, but only admit them to communion" 21 .

Cyprian was shocked by such a command. Stephen was teaching that baptism as a liturgical rite had its validity ex opere operato, i.e. by itself, if it is properly accomplished. If it is so, every heretic or schismatic can baptize; it signifies that there is no difference between the baptism received in the Church and in a sect. If it is so, there is no difference between Church and sects. If it is so,

Histoire du Christianisme, ed. J.M. Mayer et alii, vol. 2, Paris 1995, 165-166: "Dans trois conciles réunis successivement à Carthage en 255 et 256, les Pères africains, à la demande de Cyprien, réaffirmèrent solennellement la nécessité de rebaptiser les transfuges du schisme ou, plutôt, de leur administrer le seul et unique baptême valable. Toutefois, ils ne condamnaient pas expressément ceux qui refusaient cette pratique".

${ }_{19}$ Eusebius, HE VII 2-3, ed. G. Bardy, SCh 41, Paris 1955, 167-168, transl. A. Cushman McFfert, NPNF II/1, Massachusetts 1999, 293-294.

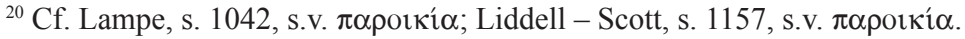

${ }^{21}$ Cyprianus, Epistula 74, 1, CSEL 3/2, 799, ANF 5, 386 (Epistula LXXIII 1). 
why pass from a sect to the Church? Cyprian was very far away from recognizing the equality of every Christian group.

Stephen explained his opinion by means of the existing tradition. As far as we know, the Churches of Rome, Palestine and Egypt followed such a tradition $^{22}$. According to G. Bareille, the Roman tradition was the oldest ${ }^{23}$. Perhaps Cyprian did not know this tradition. He criticized Stephen in his letter to Pompey. There is a statement which seems to be Cyprian's interpretation of Stephen's opinion:

"As no heresy at all, and equally no schism, being without, can have the sanctification of saving baptism, why has the bitter obstinacy of our brother Stephen broken forth to such an extent as to contend that sons are born to God from baptism of Marcion; moreover, of Valentinus and Apelles, and of others who blaspheme against God the Father; and to say that remission of sins is granted in the name of Jesus Christ where blasphemy is uttered against the Father and against Christ the Lord God?"24

This is a strong accusation against Stephen. Christians had a very bad opinion about gnosis. It was known that Marcion, Valentinus, and Apelles were famous masters of gnosis; even if they wanted to be considered as Christians, in their teaching were many points that did not conform to Christian doctrine. According to Kurt Rudolf: "the essential point of Marcion's theology is the absolute antithesis of the God of law and the God of salvation [...]. The revelation alone is the work of the «strange God»; he sent his son Jesus into the world of hopelessness and misery in order to save men from it. The body that he bore was only a phantasm (without it his entry into the evil world would have been impossible), but in it he suffered the death on the cross which the creator God had ordained him without knowing him [...]. The work of Christ is understood by Marcion, who followed Paul, primarily as redemption and as payment of a debt, in contrast to the code of criminal justice of the Demiurge [...]. As has been remarked, Marcion's teaching cannot be understood without Gnostic theology. This is true primarily of the teaching about the two Gods"25. We can add that Marcion rejected completely the Old Testament and ten letters of Saint Paul: Galatians, I and II Corinthians, Romans, I and II Thessalonians, Ephesians, Colossians, Philippians and Philemon. Marcion organized his own

${ }^{22}$ Cf. Pietri, Les résistances, p. 165: "Rome ainsi que les Églises de Palestine et d’Égypte ne pratiquent point le rebaptême des hérétiques qui se convertissaient à la vraie foi et leur conféraient seulement une imposition des mains".

${ }^{23} \mathrm{Cf}$. Bareille, Baptême des hérétics, p. 225: "La coutume romaine avait pour elle l'ancienneté et l'universalité; elle condamnait donc la coutume récente et particulière à certaines Églises d'Afrique et d'Asie".

${ }^{24}$ Cyprianus, Epistula 74, 7, CSEL 3/2, 805, ANF 5, 388 (Epistula LXXIII 7).

${ }^{25} \mathrm{~K}$. Rudolph, The Gnosis. The Nature and History of Gnosticism, transl. R. McLachlan Wilson, Edinburgh 1984, 314-315. 
church. Tertullian tried to refute his teaching in his book Adversus Marcio$n e m^{26}$. Generally, Christians had a very bad opinion about Gnostics.

Apelles was also known as a Gnostic: “Among Marcion's disciples, Apelles, who probably joined gnostic circles in Alexandria, stands out. He guided his master's teaching more strongly back again to the contemporary gnosis. He ascribed to the souls a prehistoric existence with the «good God», and made the demiurge into an angel who was created by the same God, and so blunted the edge of the radical system of the two Gods. As cause of evil and of the body, he introduced a «fiery angel» who had fallen down away and who is also the God of the Jews" ${ }^{27}$. As we see, Apelles had as bad opinion of the Jewish religion as his master Marcion had. Both rejected Jewish tradition and formed their own religion. In fact, they rejected God's revelation given by the prophets.

There was another master of gnosis; his name was Valentinus; it seems that he was the most famous among Gnostics. He founded his school in Rome. K. Rudolf gave some details from Valentinus' doctrine: "The idea of emanation inherent in the system of Valentinus with the primeval beginning, the divine depth (Bythos) at the beginning, is here expressed poetically [...]. Valentinus claimed for his teaching divine revelation, and thus gave it authority [...]. The community of Valentinus sees itself as the Church of Christ which finds its wisdom outside itself in the «inner» tradition of mankind accessible to Gnostics"28. Valentinus' teaching about Christ had nothing common with the Christian doctrine: "According to him, Christ was a son of the «Mother», i.e. of Sophia, brought forth in the remembrance of those from above, to which place he also returned, while the mother, thus abandoned, created (from the psychical elements left to her) another son, the Demiurge" 29 . We can imagine how great Cyprian's accusation against Stephen was: the Bishop of Rome accepts the baptism of famous teachers of gnosis whose system is very far away from Christianity. How could a rite of the Gnostics, similar to true baptism, forgive sins and bring regeneration for the new life in Christ? Cyprian was not able to understand how Stephen, the Bishop of Rome, could attribute any spiritual value to heretic rites. He complained:

"He forbade one coming from any heresy to be baptized in the Church; that is, he judged the baptism of all heretics to be just and lawful. And although

${ }^{26}$ Cf. Tertullianus, Adversus Marcionem lib. I 1-6.

${ }^{27}$ Rudolph, The Gnosis, p. 316-317.

${ }^{28}$ Ibidem, p. 318-319. Cf. ibidem, p. 320: "To the ideas held in common by all Valentinians belong the following which probably were typical for Valentinus too: the Pleroma consists of at least 30 eons or worlds which bear different names and are arranged on pairs (they form 15 pairs)".

${ }^{29}$ Ibidem, p. 321. Cf. ibidem, p. 322: "The school of Valentinus is one of the greatest and most influential gnostic schools before Manicheism. Of no other have we so many names and reports. Some of the disciples of Valentinus were distinguished intellectuals, such as Ptolomaeus, Heracleon, Theodotus and even Marcus". 
special heresies have special baptisms and different sins, he, holding communion with the baptism of all, gathered up the sins of all, heaped together into his own bosom. And he charged that nothing should be innovated except what been handed down; as if he (the one) were an innovator, who holding the unity, claims for the one Church one baptism; and not manifestly then (the one) who, forgetful of unity, adopts the lies and the contagions of a profane washing. Let nothing be innovated, says he, nothing maintained, except what has been handed down. Whence is that tradition? Whether does it descend from the authority of the Lord and in the Gospel, or does it come from the commands and the epistles of the apostles?"30

In the Gospels, there is no teaching about the baptism of heretics because there were no heretics in the time of Jesus. He just said after his resurrection:

"Go, then, and to all peoples everywhere and make them my disciples; baptize them in the name of the Father, the Son and the Holy Spirit, and teach them to obey everything I have commanded you" (Mt 28:19).

Jesus argued many times against the opinions of the Pharisees and their way of life. The Apostles had to face first of all the Jewish religious authorities. Heretics appeared later. The Apostles rejected Jewish opinions and warned Christians against them. According to John's Gospel, Jesus said:

"My children, the end is near! You were told that the Enemy of Christ would come; and now many enemies of Christ have already appeared, and so we know that the end is near. These people really did not belong to our fellowship, and it why they left us. If they had (really) belonged to our fellowship, they would have stayed with us. But they left so that it might be clear that none of them really belonged to us" (1Jn 2:18-20).

Peter wrote:

"These people are like dried-up springs, like clouds blown along by a storm; God has reserved a place for them in the deepest darkness. They made proud and stupid statements, and use immoral bodily lusts to trap those who are just beginning to escape from among people who live in error" (2Pet 2:17-18).

Paul gave his readers a similar teaching:

"Those men are not true apostles, who lie about their work and disguise themselves to look like real apostles of Christ. Well, no wonder! Even Satan can disguise himself to look like an angel of light. So it is no great thing if his servants disguise themselves to look like servants of righteousness. In the end they will get exactly what their actions deserve" (2Cor 11:13-15).

\footnotetext{
${ }^{30}$ Cyprianus, Epistula 74, 2, CSEL 3/2, 799-800, ANF 5, 386 (Epistula LXXIII 2).
} 
Titus received the following advice from Paul:

"Give at least two warning to those who cause divisions, and then have nothing more to do with them. You know that such people are corrupt, and their sins prove that they are wrong" (Tit 3:10).

Indeed, the Apostles warned Christians against errors in religion. According to The Oxford Bible Commentary, he thought about Jewish Christians ${ }^{31}$. Neither John, nor Peter nor Paul wrote about the validity of the baptism heretics. Perhaps in that time there were no people who after having received baptism in a sect wanted to join the Church. If they were baptized in the Church and later passed to a sect, their baptism was considered valid there. For that reason the Apostles did not give a clear teaching about the validity of the baptism administrated in sects.

Indeed, Stephen could not prove his decision on baptism by quotations from the New Testament. What he gave as a norm was his own opinion, maybe based on the tradition of some Churches. Stephen's teaching was accepted by the bishops of Italy and other provinces. The conflict was great. Theological debate was necessary. The context was difficult because it was the time of persecutions. So, there were two battles in the same time: Roman authorities, i.e. pagans, were attacking Christians and forcing them to apostasy, while Christians were fighting among themselves. There were people who - by fear - abandoned their faith and became apostates $(\text { lapsi })^{32}$. There were people who - by error - joined heterodox groups and became heretics. And there were people among apostates (lapsi) and among heretics who wanted to join the Catholic Church. There was a great disorder, but in spite of it evangelization was progressing.

3. The position of Firmilian of Caesarea. Cyprian was not alone with his opinions. Most bishops of Africa supported him, except those of Mauretania; they adopted the position of the Church of Rome ${ }^{33}$. Cyprian had great authority in Africa as a theologian and a man of personal sanctity. He occupied the prestigious bishopric of the see of Carthage. This city was like a capital city of North Africa. According to the tradition of that time, bishops remained in touch by correspondence. Cyprian informed Firmilian, Bishop of Caesarea, about the letter from Stephen, Bishop of Rome. He gave his explanation on the validity

${ }^{31}$ Cf. The Oxford Bible Commentary, ed. J. Barton - J. Muddiman, Oxford 2001, 1233: "That the difficulties are caused by Jewish Christian sis suggested by the fact that some of the debates concern the Law".

${ }^{32}$ Cf. P. Szczur, Lapsi, EK X 495-496.

${ }^{33}$ Cf. Pietri, Les résistances, p. 165: "Cyprien fut douloureusement surpris par la contestation venue de Maurétanie africaine : les évêques de cette région, moins étroitement rattachés à Carthage que ceux de Proconsulaire et de Numidie, tendaient à s'aligner sur l'usage romain". See Szczur, Lapsi, EK X 495-496 
of the baptism of heretics. Firmilian answered him, saying that he also rejected the baptism of heretics ${ }^{34}$. He gave many arguments to prove his opinion. Generally, Churches in Syria and in Asia Minor followed Cyprian's, i.e. Africa's tradition $^{35}$. Firmilian wrote on his own behalf and he presented the opinion of the bishops who had discussed this question on the synod in Iconium ${ }^{36}$.

a. Firmilian's opinion: there is no teaching of the Apostles on the baptism of heretics. Stephen tried to explain his position by referring to the Holy Scripture. Firmilian contested his explanation. He wrote in his letter:

"Since that messenger sent by you was in haste to return to you, and the winter season was pressing, we replied what we could to your letter. And indeed, as respects what Stephen has said, as though the apostles forbade those who come from heresy to be baptized, and delivered this also to be observed by their successors, you have replied most abundantly, that no one is so foolish as to believe that the apostles delivered this, when it is even known that these heresies themselves, execrable and detestable as they are, arose subsequently; when Marcion the disciple of Cerdo is found to have introduced his sacrilegious traditions against God long after the apostles, and after long lapse of time from them. Apelles, also consenting to his blasphemy, added many other new and more important matters hostile to faith and truth. But also the time of Valentinus and Basilides is manifested, that they too, after the apostles, and after a long period, rebelled against the Church of God with their wicked lies" ${ }^{\prime 37}$.

Firmilian proves that the acceptance of the baptism of heretics could not be commanded by the Apostles, because main heresies appeared later, after the Apostolic period. Firmilian speaks of the Gnostic groups of Marcion, Basilides, Valentinus and Cerdo (Kerdon) whose teaching could be considered as a caricature of Christian doctrine. It was obvious for most Christians that nothing should be accepted from gnosis. How could they accept their baptism? As there is no teaching in the Bible about the validity of the baptism of heretics, Firmilian rejects Stephen's opinion as purely human:

"And yet on this account there is no departure at all from the peace and unity of the Catholic Church, such as Stephen has now dared to make; breaking the peace against you, which his predecessors have always kept with you in

${ }^{34} \mathrm{Cf}$. Ibidem, p. 166: “Défendant l'usage asiate semblable à celui d'Afrique, et assuré de l'appui de ses collègues orientaux, Firmilien de Césarée (de Cappadoce) envenima le débat par sa violence verbale extrême, en comparant Étienne à Judas".

${ }^{35}$ Cf. Ibidem, p. 165: "L'Église d'Afrique et celles de Syrie et d'Asie Mineure considéraient qu'un baptême administré par un ministre indigne était sans valeur et devait donc être réitéré".

${ }^{36} \mathrm{Cf}$. Bareille, Baptême des hérétiques, p. 222: "Cyprien, qui avait assisté au synode d'Iconium, approuva la conduite de Cyprien, et écrit une lettre des vives contre l'évêque de Rome".

${ }^{37}$ Cyprianus, Epistula 75, 5, CSEL 3/2, 813, ANF 5, 391 (Epistula LXXIV 5). 
mutual love and honour, even herein defaming Peter and Paul the blessed apostles, as if the very men delivered this who in their epistles execrated heretics, and warned us to avoid them. It appears that this tradition is of men who are heretics and assert that they have baptism which belongs to the Church"38.

According to Firmilian, Stephen introduced a new tradition which was contradictory to the position of Peter and Paul who commanded Christians to avoid heretics. By his innovation, he defamed the Apostles by his decision concerning the baptism of heretics.

b. Firmilian's theological explanation of his rejection of the baptism of heretics. The question was important: Did people baptized by heretics have their sins forgiven or not? Firmilian, following Cyprian, believed that remission of sins was possible only in the Church, not in sects. He tried to prove his opinion with arguments from the New Testament. He wrote:

"As Stephen and those who agree with him contend that putting away of sins and second birth may result from the baptism of heretics, among whom they themselves confess that the Holy Spirit is not. Let them consider that and understand that spiritual birth cannot be without the Spirit; in conformity with which also the blessed Apostle Paul baptized anew with a spiritual baptism those who had already been baptized by John before the Holy Spirit had been sent by the Lord, and so laid hands on them that they might receive the Holy Spirit. But what kind of thing is it, that when we see that Paul, after John's baptism, baptized his disciples again, and we hesitate to baptize those who come to the Church from heresy after their unhallowed and profane dipping" ${ }^{\prime 39}$.

Firmilian believed that the validity of baptism issued not from a rite but from the Holy Spirit. It is the Spirit who produces regeneration (regeneratio). There was a conviction that the Holy Spirit was working only in the Church. If the Holy Spirit is absent among heretics, their baptism is not valid.

Firmilian underlined that Saint Paul understood the difference between John's baptism and Christian baptism. We read in the Acts of the Apostles:

"While Apollos was in Corinth, Paul travelled through the interior of the province and arrived in Ephesus. There he found some disciples and asked them: «Did you receive the Holy Spirit when you became believers»? They answered: «We have not even heard that there is a Holy Spirit». Paul asked: «Well, then, what kind of baptism did you receive»? They answered: «The baptism of John». Paul said: «The baptism of John was for those who turned from their sins; and he told the people of Israel to believe in the one who was coming after him, that is, in Jesus. When they heard this, they were baptized in the name of the Lord Jesus. Paul placed his hands on them; and the Holy

\footnotetext{
${ }^{38}$ Ibidem 75, 6, CSEL 3/2, 813-814, ANF 5, 391 (Epistula LXXIV 6).

${ }^{39}$ Ibidem 75, 8, CSEL 3/2, 815, ANF 5, 392 (Epistula LXXIV 8).
} 
Spirit came upon them. They spoke in strange tongues and proclaimed God's message»" (Acts 19:1-6).

The idiom "baptism in the name of the Lord Jesus" means "Christian baptism", i.e. the baptism in the name of the Father and of the Son and of the Holy Spirit (in nomine Patris et Filii et Spiritus Sancti) ${ }^{40}$. Such a rite of baptism was used since the beginning of Christianity according to Jesus Christ's command: "Go, then, to all peoples and everywhere and make them my disciples: baptize them in the name of the Father and of the Son and of the Holy Spirit" (Mt 28:18). Christian baptism has always been connected to the proclamation of God's Word and of personal conversion. There was no doubt that the whole Trinity was acting in the Church's actions (in sacramentis). Those who were baptized had to follow God's commandments and remain in the Christian community. They were also called to enter by faith into the Community of the Father and the Son and the Holy Spirit ${ }^{41}$.

By referring to Saint Paul, Firmilian wanted to say: As Paul baptized those disciples, even if they had already received the baptism of John, as Church authorities should baptize once again those who come from heresies. Then, they will be able to receive the Holy Spirit, and consequently - forgiveness of their sins. Firmilian continued:

"If the baptism of heretics can have the regeneration of the second birth, those who are baptized among them must be counted not heretics, but children of God. For the second birth, which occurs in baptism, begets sons of God. But if the spouse of Christ is one, which is the Catholic Church, it is she herself who alone bears sons of God. There are not many spouses of Christ (neque enim multae sponsae Christi)" ${ }^{\prime \prime 2}$.

It is easy to realize his way of thinking: if the baptism of heretics is valid and bears sons of God, there is no difference between Church and sects. In fact, the Church as spouse of Christ is one, so there should be one faith and one baptism. If the baptism of heretics is valid, there is then no reason to leave a sect and join the Catholic Church. In other words: If people can obtain the same God's gifts in the Church and in a sect, there is no need to move; they can remain in their sects. Those who admit such a possibility can say that there are many spouses of Christ. That would be a spiritual polygamy! It was clear for Firmilian that such reasoning was leading to absurdity. Bishops, Firmilian and Cyprian, and many others, desired to keep the unity of Christianity. There

${ }^{40} \mathrm{Cf}$. R. Béraudy, L'Initiation chrétienne, dans l'Église en prière. Introduction à la Liturgie, ed. A.G. Martimort, Tournai 1961, 519: "Pour reconstituer le rite baptismal romain du $\mathrm{II}^{\mathrm{e}}$ au Ve siècle, nous disposons de documents relativement nombreux [...]. Celui qui baptisait descendait dans la piscine avec le candidat. Il l'interrogeait successivement sur sa foi au Père, au Fils et à l'Esprit-Saint'.

${ }^{41} \mathrm{Cf}$. Irenaeus Lugdunensis, Demonstratio praedicationis apostolicae 7.

${ }^{42}$ Cyprianus, Epistula 75, 14, CSEL 3/2, 819, ANF 5, 393 (Epistula LXXIV 14). 
were not ready to look for compromising with separated groups and their leaders. Eugeniusz Sakowicz writes that "humanity called to dialogue lived in monologues, and even assigned to this monologue a sort of cultic status" ${ }^{\text {" }}$. The idea of ecumenical dialogue appeared in Christianity many centuries later.

c. Firmilian's opinion on the inefficacy of the baptismal rite used by heretics. Pope Stephen presented the opinion that if this rite is performed properly, it produces by itself an effect (ex opere operato). He believed that baptism as a sacrament is valid in spite of the human indignity, because it is Christ himself who is acting in baptism ${ }^{44}$. Firmilian rejected such a point of view. He wrote:

"That, moreover, is absurd, that they do not think it is to be inquired who was the person that baptized, for the reason that he who has been baptized may have obtained grace by the invocation of the Trinity, of the names of the Father, and of the Son, and of the Holy Spirit [...]. They say, he, who in any manner whatever is baptized, may obtain the grace of baptism by his disposition and faith, which doubtless is ridiculous in itself, as if either a wicked disposition could attract to itself from heaven the sanctification of the righteous, or a false faith (could attract) the truth of believers. But that not all who call on the name of Christ are heard, and that their invocation cannot obtain any grace, the Lord himself manifests, saying: «Many shall come in my name saying, I am Christ, and shall deceive many» (Mk 13:6). There is no difference between a false prophet and a heretic. For as the former deceives in the name of God or Christ, so the latter deceives in the sacraments of baptism. Both strive by falsehood to deceive men's will' ${ }^{15}$.

As we see, Firmilian argues Stephen's position. When heretics invoke the Father and the Son and the Holy Spirit, they do it only for seducing people. Heretics act as false prophets; they are pretending to proclaim God's message, but in fact they lie. According to Firmilian, it is not enough to invoke the name of Christ:

"He says: «The name of Christ is of great advantage to faith and the sanctification of baptism; so that whosoever is anywhere so ever baptized in the name of Christ, immediately obtains the grace of Christ». This position may be briefly met and answered: If baptism in the name of Christ availed for the cleansing of man, in the name of the same Christ, the imposition of hands might avail also for the reception of the Holy Spirit; and the other things also

${ }^{43}$ E. Sakowicz, Dialogue and Identity, CT 69 (1999) fasc. spec., 173.

${ }^{44}$ Cf. Bareille, Baptême des hérétiques, p. 228: "Étienne plaça la validité du baptême dans l'emploi régulier de la formule trinitaire, abstraction faite du ministre et du sujet [...]. Sa validité provient de l'efficacité de la formule trinitaire, de la vertu du nom de Jésus-Christ [...]. Le baptême des hérétiques, quels qu'ils soient, est dès lors juste et légitime".

${ }^{45}$ Cyprianus, Epistula 75, 9, CSEL 3/2, 815-816, ANF 5, 392 (Epistula LXXIV 9). 
which are done among heretics will begin to seem just and lawful when they are done in the name of Christ" ${ }^{\prime 4}$.

Firmilian rejects the principle ex opere operato. The liturgical rite is not important, even if it is properly accomplished, but remaining in unity with the Church. Any sacramental action accomplished out of the Church, even if it formally accomplished in the name of Christ, is not valid, it has no effect, it grants no God's grace, and it produces no spiritual regeneration.

Firmilian tries to prove his opinion by an extreme case that happened in his country:

"There arose among as on a sudden a certain woman, who in a state of ecstasy announced herself as a prophetess, and acted as if filled with the Holy Spirit. As she was so moved by the impetus of the principal demons, that for a long time she made anxious and deceived the brotherhood, accomplishing certain wonderful and pretentious things, and promised that she would cause the earth to be shaken [...]. That woman, who previously by wiles and deceitfulness of the demon was attempting many things for the deceiving of the faithful, among other things, by which she had deceived many, also had frequently dared this: to pretend that with an invocation not to be condemned she sanctified bread and celebrated the Eucharist, and to offer sacrifice to the Lord, not without the sacrament of the accustomed utterance; and also to baptize many, making use of the usual and lawful words of interrogation, that nothing might seem to be different from the ecclesiastical rule"47.

As far as we know, such things happen from time to time in Christianity. People dominated by evil powers are able to accomplish strange things, for example to speak in foreign languages. This woman was detected by an exorcist, i.e. a priest experienced in expelling demons. There is still such a ministry in the Church. Firmilian writes:

"For all of a sudden there appeared unto her one of the exorcists, a man approved and always of good conversation in respect of religious discipline; he, stimulated by the exhortation also of very many brethren in the faith, raised himself up against that wicked spirit to overcome it [...]. Yet that exorcist, inspired by God's grace, bravely resisted, and showed that the one who was before thought holy, was indeed a most wicked spirit" ${ }^{\text {"48. }}$.

After having told this story, Firmilian asks:

"What, then, shall we say about the baptism of this woman, by which a most wicked demon baptized through means of a woman. Do Stephen and those who agree with him approve of this also, especially when neither the symbol

\footnotetext{
${ }^{46}$ Ibidem 75, 18, CSEL 3/2, 822, ANF 5, 395 (Epistula LXXIV 18).

${ }^{47}$ Ibidem 75, 10, CSEL 3/2, 817-818, ANF 5, 393 (Epistula LXXIV 10).

${ }^{48}$ Ibidem, CSEL 3/2, 817, ANF 5, 393 (Epistula LXXIV 10).
} 
of the Trinity nor the legitimate and ecclesiastical interrogatory ${ }^{49}$ was wanting to her? Can it be believed that either remission of sins was given, or the regeneration of the saving laver duly completed, when all things, although after the image of truth, yet were done by a demon? Unless, perchance, they who defend the baptism of heretics contend that the demon also conferred the grace of baptism in the name of the Father and of the Son and of the Holy Spirit. Among them, no doubt, there is the same error; it is the very deceitfulness of devils, since among them the Holy Spirit is not at all" ${ }^{50}$.

Firmilian wanted to show by this story the absurdity of the opinion that in baptism it is not the person of the baptizer who is important but the rite itself; he ridicules the opinion that baptism is valid if the rite was properly accomplished, no matter who accomplished it. In that case, the baptismal rite was respected, but the minister was demon acting through a woman! Is it possible, Firmilian asks, that the demon can produce regeneration? Is it possible that an impure spirit can forgive sins? Is it possible that the devil can grant God's grace? It was obvious to him and to many others that no: the baptism administrated by that woman was not valid; her attempt to consecrate bread and wine (to imitate the Eucharistic celebration) had no effect. The same should be said about the ceremonies of heretics; they have no value. It was obvious to Firmilian that Stephen's position was wrong:

"In this respect I am justly indignant at this so open and manifest folly of Stephen, that he who is so boasts of the place of his episcopate, and contends that he holds the succession from Peter, on whom the foundation of the Church were laid, should introduce many other rocks and establish new buildings of many churches; maintaining that there is baptism in them by his authority. For they who are baptized, doubtless, fill up the number of the Church. But he who approves their baptism maintains, of those baptized, that the Church is also with them. Nor does he understand that the truth of the Christian Rock is overshadowed, and in some measure abolished, by him when he thus betrays and deserts unity [...]. Stephen who announces that he holds by succession the throne of Peter (cathedram Petri), is stirred with no zeal against heretics, when he concedes to them, not a moderate, but the very greatest power of grace: so far as to say and assert that, by the sacrament of baptism, the filth of the old man is washed away by them, that they pardon the former mortal sins,

${ }^{49}$ By the "ecclesiastical interrogatory" three questions were understood. The priest or bishop asked the person who was baptized: «Do you believe in God the Father? Do you believe in the Son? Do you believe in the Holy Spirit?» The baptized person should answer each question saying: «Yes, I do». Such an interrogatory is to be found for example in the Traditio apostolica 21, attributed to Hippolytus of Rome. We do not discuss here the complicated question of the authorship of this book. Cf. P. Nautin, Hippolyte et Josipe: contribution de la littérature chrétienne du troisième siècle, Paris 1947, 34-72; J. Grzywaczewski, Hippolyte an Enigmatic Figure, Lublin 2014, 37-44.

${ }^{50}$ Cyprianus, Epistula 75, 11, CSEL 3/2, 818, ANF 5, 393 (Epistula LXXIV 11). 
that they make sons of God by heavenly regeneration, and renew to eternal life by the sanctification of the divine laver" ${ }^{\prime \prime}$.

As we see, Firmilian is very severe with Stephen; Firmilian caricatures his position towards heretics. He does not hesitate to speak about the "folly of Stephen". He accuses him of putting the Church and heresies on the same level. He deplores that he makes errors, even if he pretends to hold by succession the throne of Peter. Indeed, Stephen presented himself as successor of Saint Peter $^{52}$. Before him, theologians spoke rather about the authority of the Church of Rome, based on the tradition of Saint Peter and Paul ${ }^{53}$. Firmilian refers to Stephen's position as Bishop of Rome, but without discussing directly the question of his authority over all of Christianity.

Stephen was not able to make peace in the Church during his life. He died in 257. It seems that his successor, Pope Sixtus, had more of a chance. He made efforts to restore union among Churches. Theologians suppose that he achieved reconciliation with Cyprian who moderated his position softly ${ }^{54}$. The question of the baptism of heretics appeared once again in the fourth century. The synod of Arles (314) made the following decision:

"Having in view the Africans who according to their own law baptize once again (propria lege sua utuntur ut rebaptizent), we have decided to act as follows: If a heretic comes to the Church, he should be asked what his symbol (symbolum) of faith is. If he is baptized in the name of the Father and of the Son and of the Holy Spirit, only hands should be laid on him, so that he receives the Holy Spirit. If he is asked and does not answer speaking about the

${ }^{51}$ Ibidem 75, 17, CSEL 3/2, 821, ANF 5, 394-395 (Epistula LXXIV 17).

${ }^{52}$ Cf. K. Schatz, La primauté du Pape, trad. J. Hoffmann, Paris 1992, 32: "La controverse concernant le baptême conféré par les hérétiques (255-256) fait apparaître une étape de plus dans la conscience que Rome avait de sa primauté. À présent l'évêque de Rome ne se réfère plus seulement au fait que la tradition romaine tire sa légitimité de Pierre et Paul, mais il se considère lui-même comme le successeur de Pierre et comme celui qui détient l'autorité dont parle Mt 16, 18". See Ibidem, p. 33: "Étienne semble s'être référé à la succession de Pierre au sens de Mt 16:18. Il s'agit là du premier cas connu où Mt 16:18 est appliqué à l'évêque de Rome".

${ }^{53}$ Cf. V. Saxer, La mission de l'Église au III' siècle, in: Histoire du Christianisme, p. 71: "La primauté de Pierre est regardée non pas comme une supériorité de droits et de pouvoirs, mais comme une simple antériorité, une espèce de primogéniture de droits étendus ensuite à tous les apôtres".

${ }^{54}$ Cf. Pietri, Les résistances, p. 166: "Étienne mourut sur ces contrefaites (août 257), et son successeur Sixte paraît être en communion avec Cyprien comme avec les évêques orientaux. La question du baptême des hérétiques n'avait pas été tranchée et devait réapparaître au IV siècle, suscitant de nouveaux remous". 
Holy Trinity (si interrogates non responderit hanc Trinitatem), he should be baptized (baptizetur)" ${ }^{55}$.

The Roman position on this matter has been generally accepted in the Catholic Church. In the fifth century, the Donatists in Africa followed Saint Cyprian's position; they did not recognize the baptism received in the Catholic Church, but Saint Augustin recognized the baptism administrated by Donatists ${ }^{56}$. Generally, this tradition was accepted by most Christian denominations and it has been followed until our times.

\section{WAŻNOŚĆ CHRZTU HERETYKÓW WEDŁUG CYPRIANA Z KARTAGINY, PAPIEŻA STEFANA I FIRMILIANA Z CEZAREI}

\section{(Streszczenie)}

Artykuł dotyczy debaty nad ważnością chrztu, jaka toczyła się w 2. poł. III w. pomiędzy biskupem Rzymu Stefanem a Cyprianem z Kartaginy i Firmilianem z Cezarei. Stefan przyjmował obiektywną skuteczność sakramentów (ex opere operato) i prezentował pogląd, że chrzest udzielany w sektach jest ważny. Wymienieni biskupi temu przeczyli. Według biskupa Rzymu w rycie sakramentalnym działa sam Chrystus. Według Cypriana i Firmiliana chrzest stanowi wprowadzenie do Kościoła. Heretyk nie może nikogo wprowadzić do Kościoła, skoro sam do niego nie należy. Obradowano nad tym zagadnieniem z Rzymie, w Kartaginie oraz w Ikonium. Pomimo rozbieżności opinii nie doszło do formalnego rozłamu w Kościele. Później zwyciężyła w chrześcijaństwie tradycja rzymska, według której chrzest udzielany poza Kościołem jest ważny.

Key words: Cyprian, Firmilian, Stephen, baptism, ex opere operato, heretics.

Slowa kluczowe: Cyprian, Firmilian, Stefan, chrzest, ex opere operato, heretycy.

${ }^{55}$ Concilium Arelatense (314) can. 9(8), ed. in: SCL 1, Kraków 2006, 72, own translation.

${ }^{56}$ Cf. A. Żurek, Chrzest a zbawienie człowieka: ważność i konieczność chrztu w świetle polemiki Augustyna z donatystami, VoxP 26 (2006) t. 49, 756. 